\title{
Horizontal continuous and apical stretching sutures does not reduce FGG shrinkage: A split-mouth randomized controlled clinical trial
}

\section{Purpose}

This study aimed to evaluate whether horizontal continuous and apical stretching sutures could reduce FGG shrinkage.

\section{Materials and Methods}

In this randomized controlled clinical trial ten patients (20 sites, seven females and three males) ranging from 18 to 53 years (average 39 years) with insufficient keratinized and attached gingiva received FGG in two quadrants of mandible (splitmouth design). Horizontal continuous and apical stretching sutures were used in test sites in addition to common suturing techniques. Clinical parameters including probing depth (PD), the width of keratinized and attached gingiva (KG, AG), the horizontal and vertical dimension of the graft (HD, VD), and graft area (GA) were recorded at baseline and 1,3 , and six months after the operation.

\section{Results}

PD did not differ significantly for six months. The average change of other parameters in test and control sites respectively was as follows: KG increased $5.5 \mathrm{~mm}$ and 5.1 $\mathrm{mm}$, AG increased $5.3 \mathrm{~mm}$ and $5.1 \mathrm{~mm}$, HD shrinkage was $21.6 \%$ and $15.8 \%$, VD shrinkage was $33.7 \%$ and $33.2 \%$, GA shrinkage was $47.3 \%$ and $43.3 \%$. There were no significant differences between test and control sites in clinical parameters six months after surgery.

\section{Conclusion}

Application of horizontal continuous and apical stretching sutures does not reduce FGG shrinkage.

Keywords: Free gingival graft; graft shrinkage; continuous horizontal suture; apical stretching suture; probing depth

\section{Introduction}

The free gingival graft (FGG) is a surgical procedure which is used to increase the keratinized tissue around the teeth $(1,2)$. It is the oldest surgical technique in periodontal surgery (3). In this procedure, the graft is obtained from the palate or the maxillary tuber. The FGG is the gold standard for the gingival augmentation procedures a procedure that is used to increase keratinized tissue around teeth (4). Dentists use FGG in the clinical situations that thin gingiva might be less protective in the presence of inflammation and gingival recession. Orthodontic treatment, inadequate plaque control, high frenulum attachment, and shallow vestibular depths are the leading causes of mucogingival problems (5).

After utilization of FGG, the vestibular depth of recipient area may be diminished by contraction of wound and reinsertion of muscle fibers in postoperative stage (6). Therefore, dimensional changes including the

\author{
Amir Shammas' $\mathbb{1}$, \\ Hadi Ranjbar ${ }^{2}$ (D), \\ Mohadeseh Arab Solghar ${ }^{3}$ (D), \\ Najme Asghari ${ }^{4}$ (1), \\ Mohammad Mohammadi 5 (D)
}

ORCID IDs of the authors: A.S. 0000-0001-6389-6420 H.R. 0000-0002-3672-7266; M.A.S. 0000-0003-1152-1314 N.A. 0000-0002-9908-0981; M.M. 0000-0001-6257-6126

${ }^{1}$ University of Medical Sciences, Dental School, Department of Periodontics, Birjand, Iran

2Iran University of Medical Sciences, Tehran Institute of Psychiatry-School of Behavioral Sciences and Mental Health, Mental Health Research Center, Tehran, Iran

${ }^{3}$ Kerman University of Medical Sciences, Dental School, Department of Periodontics, Kerman, Iran

${ }^{4}$ Kerman University of Medical Sciences, Kerman, Iran

${ }^{5}$ Kerman University of Medical Sciences, Dental School, Department of Periodontics, Kerman, Iran

Corresponding Author: Mohammad Mohammadi

E-mail: m_mohammadi@kmu.ac.ir

Received: 21 January, 2019 Revised: 25 August, 2019 Accepted: 26 September, 2019

DOI: $10.26650 /$ eor.20200080 
contraction of transplanted tissue may occur, especially in long-term follow-up, and as a result, expected treatment outcome including a satisfied amount of new keratinized tissue may not be achieved (6). The other factors affecting on FGG shrinkage are phenotype of the periodontium, the thickness of graft, and type of periosteal bed in the term of preserving periosteum or not (7-9). Suturing technique has been considered as an essential factor affecting graft shrinkage. According to Oschenbein, stretching the graft by continuous horizontal suture may counteract the first contraction and make the graft more receptive to revascularization by influencing the collapsed blood vessels (10). Furthermore, Miller proposed apical stretching suture to prevent coronal movement of the graft and reduce shrinkage by keeping the vascular channels patent within the graft (11). It is essential to accomplish this operation with as low as a possible number of sutures in order to reduce trauma to the graft (10). To our knowledge so far, no study has analyzed the effect of horizontal continuous and apical stretching sutures on graft contraction. Therefore the purpose of this study was to evaluate whether horizontal continuous and apical stretching sutures could reduce FGG shrinkage.

\section{Materials and Methods}

\section{Study design}

In this split-mouth randomized controlled clinical trial, 10 patients ( 7 females and 3 males) ranging from 18 to 53 years (average 39 years) with insufficient keratinized and attached gingiva (keratinized gingiva $<2 \mathrm{~mm}$, attached gingiva $<1$ $\mathrm{mm}$ ) in premolar regions of mandible were selected based on their need to bilateral gingival augmentation due to oral hygiene procedures or prosthetic or orthodontic reasons or two-stage root coverage. Exclusion criteria were systemic diseases contraindicated periodontal surgery, pregnancy, breastfeeding, taking medications affecting on periodontium such as phenytoin, smoking, and full mouth plaque index and bleeding index> 20\%. All patients received the treatment protocol and accepted the detailed informed and written consent. The ethics committee approved this research in Kerman University of Medical Science (Ethics code: $\mathrm{KA} / 90 / 180$ ) and registered through the IRCT website with the number IRCT201608205305N5.

Full mouth scaling and root planing and oral hygiene enhancement were performed for all patients one month before surgery. The width of keratinized gingiva (distance from gingival margin to the mucogingival junction) by Roll technique and the probing depth in the midbuccal region was measured with a Michigan-O-Probe (Hu-Friedy, USA) to the nearest $1 \mathrm{~mm}$. The width of the attached gingiva in the midbuccal region was evaluated by subtracting probing depth from the width of keratinized tissue. All measurements were performed by an experienced periodontist who was blind to the study. Two sites in each patient were randomly assigned to test or control with throwing a coin (simple randomization).

\section{Surgical procedure}

Each patient received free gingival graft in test and control sites at the same visit. The local anesthetic (Lidocaine
$2 \%$ with epinephrine $1 / 80000$ ) was administrated to recipient and donor sites. At the recipient site, a $15 \mathrm{C}$ scalpel (Hu-Friedy, USA) was utilized to make a $10 \mathrm{~mm}$ horizontal incision in mucogingival junction with two $9 \mathrm{~mm}$ vertical incisions in mesial and distal extensions. A partial thickness bed was prepared with a scalpel. A Mucotome (PR4, DEPPEL$E R$, Swiss) was used to harvest a $9 \times 10 \mathrm{~mm}$ free gingival graft with homogenous thickness $(1.5 \mathrm{~mm})$ from the palatal area of premolar and first molar teeth. The donor site was sutured by the arbitrary technique with 4-0 silk suture (SUPA medical devices, IRAN) to control bleeding and protected with periodontal dressing (Coe-Pak, GC, Japan). The size of the graft was measured midway in vertical and horizontal directions using a Michigan-O-Probe (Hu-Friedy, USA). The graft was sutured to the recipient region by SERALON 4-0 suture (SERAG-WIESSNER Co., Germany). The usual suturing techniques (conventional sutures) which have been used at test and control sites included two interrupted sutures in coronal and two interrupted sutures in mesial and distal of the graft and one circumferential suture (10). The latter was placed through the periosteum apical to the recipient bed slightly below the inferior border of the graft and carried around the cervical region of the tooth and tied (Figure 1). Two additional suturing techniques which considered only at test sites included horizontal continuous and apical stretching sutures. So we used combined sutures in test sites (Figure 2). The continuous horizontal suture was placed approximately midway corono-apically across the graft. First, the graft was tied at its distal margin to the underlying periosteum. The suture was not cut, but it was carried anteriorly across the
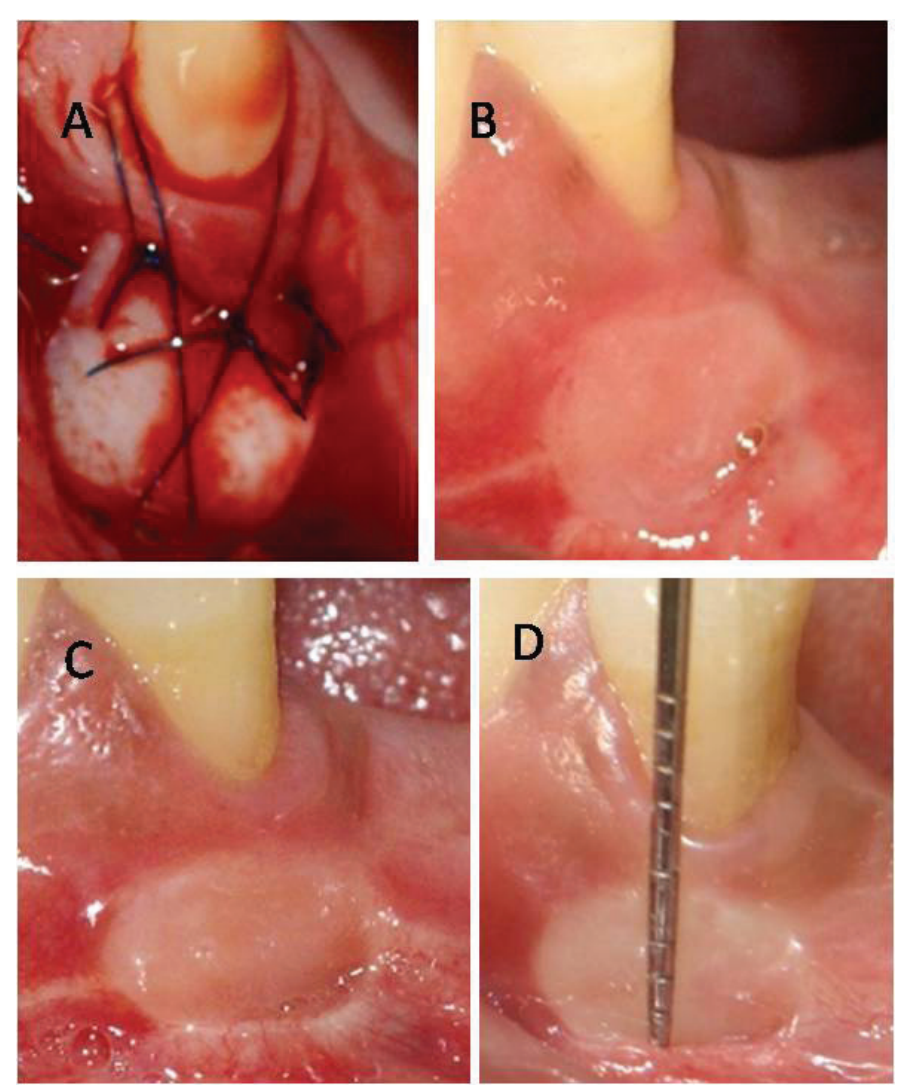

Figure 1. Interrupted sutures in coronal, mesial and distal of the free gingival graft and one circumferential suture at control site $(A)$. Free gingival graft dimensions $1(B), 3(C)$, and $6(D)$ months after the operation. 
graft with the needle passing through the mesial margin of the graft and exiting at its undersurface. Slack was left in the portion of the suture that extended across the body of the graft. The needle entered the periosteum at a sufficient distance from the mesial border of the graft so that the graft
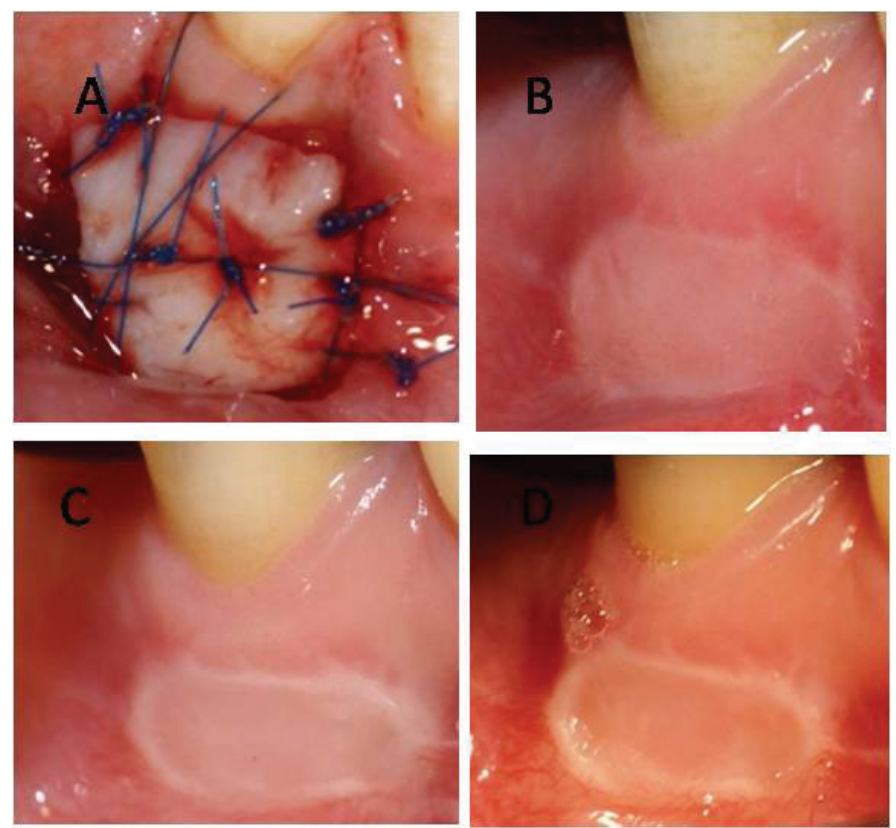

Figure 2. Two additional suturing techniques which considered only at test sites were horizontal continuous and apical stretching sutures (A). Free gingival graft dimensions $1(B), 3(C)$, and $6(D)$ months after the operation. could be stretched adequately, ordinarily 2-3 $\mathrm{mm}$. The suture end that had exited from the periosteum was tied to the loop formed by the slack. In the apical stretching technique two interrupted sutures with distal angulation tied the periosteum to the mesio-apical and disto-apical borders of the graft. The periodontal dressing (Coe-Pak, GC, Japan) was finally placed on the graft at test and control sites. All surgery procedures were performed by a periodontist who was not blind to the study.

\section{Postsurgical care}

Patients have prescribed $0.2 \%$ chlorhexidine mouthwash and instructed to rinse gently twice daily for two weeks. Tooth brushing activities in the operated sites were discontinued during this time. They were also given ibuprofen (400 $\mathrm{mg}$, four times daily in the case of feeling pain) and amoxicillin (500 mg, three times daily for one week). The periodontal dressing and sutures were removed two weeks after surgery, and then mechanical supra-gingival plaque control was permitted.

\section{Postsurgical evaluation}

Clinical parameters which were evaluated after surgery included probing depth (PD), the width of keratinized and attached gingiva (KG, $A G$ ), the horizontal and vertical dimension of the graft (HD, VD), and graft area (GA). KG and $P D$ in the midbuccal region were measured with a Michigan-O-Probe (Hu-Friedy, USA) to the nearest $1 \mathrm{~mm}$. AG in

Table 1: Clinical parameters at baseline, 1,3, and six months after surgery at test and control sites, and comparison of these clinical parameters between test and control sites.

\begin{tabular}{|c|c|c|c|c|c|c|}
\hline $\begin{array}{l}\text { Clinical } \\
\text { parameters }\end{array}$ & $\begin{array}{l}\text { Baseline } \\
\text { Mean } \pm \text { SD }\end{array}$ & $\begin{array}{l}1 \text { month } \\
\text { Mean } \pm \text { SD }\end{array}$ & 3 months Mean \pm SD & 6 months Mean \pm SD & $\begin{array}{l}\text { Within } \\
\text { groups } \\
\text { P value }\end{array}$ & $\begin{array}{l}\text { Between } \\
\text { groups P } \\
\text { Value }\end{array}$ \\
\hline
\end{tabular}

\begin{tabular}{lllllll}
\hline \multicolumn{7}{c}{ Probing depth } \\
\hline Test & $1.30 \pm 0.67$ & $1.30 \pm 0.48$ & $1.30 \pm 0.48$ & $1.10 \pm 0.31$ & 0.258 & 0.800 \\
Control & $1.10 \pm 0.31$ & $1.20 \pm 0.42$ & $1.10 \pm 0.31$ & $1.10 \pm 0.31$ & 0.343 &
\end{tabular}

\begin{tabular}{lllllll}
\multicolumn{7}{c}{ The width of keratinized gingiva } \\
\hline Test & $1.50 \pm 0.84$ & $7.70 \pm 1.25$ & $7.20 \pm 1.61$ & $7.00 \pm 1.63$ & 0.00 & 0.323 \\
Control & $1.90 \pm 0.56$ & $7.30 \pm 1.15$ & $6.70 \pm 1.15$ & $7.00 \pm 1.49$ & 0.00 &
\end{tabular}

\section{The width of attached gingiva}

\begin{tabular}{llllccc} 
Test & $0.6 \pm 0.69$ & $6.40 \pm 1.42$ & $5.90 \pm 1.91$ & $5.90 \pm 1.85$ & 0.00 & 0.805 \\
Control & $0.80 \pm 0.63$ & $6.10 \pm 1.44$ & $5.60 \pm 1.34$ & $5.90 \pm 1.66$ & 0.00 & \\
& & & Horizontal dimension of graft & \\
\hline Test & $9.70 \pm 0.94$ & $8.90 \pm 1.10$ & $8.00 \pm 1.24$ & $7.60 \pm 1.57$ & 0.005 & 0.505 \\
Control & $9.50 \pm 0.70$ & $9.10 \pm 1.10$ & $7.90 \pm 1.44$ & $8.00 \pm 1.41$ & 0.040
\end{tabular}

Vertical dimension of graft

\begin{tabular}{llllll}
\hline Test & $8.90 \pm 0.99$ & $6.40 \pm 1.42$ & $5.90 \pm 1.91$ & $5.90 \pm 1.85$ & 0.007 \\
Control & $8.70 \pm 0.82$ & $6.10 \pm 1.44$ & $5.60 \pm 1.34$ & $5.90 \pm 1.66$ & \\
\multicolumn{5}{c}{ Graft area } \\
\hline Test & $86.60 \pm 15.39$ & $57.30 \pm 15.07$ & $48.40 \pm 21.39$ & $45.60 \pm 18.33$ & 0.001 \\
Control & $82.90 \pm 12.35$ & $55.40 \pm 14.48$ & $44.10 \pm 13.16$ & $47.00 \pm 15.07$ & 0.003 \\
\hline
\end{tabular}


the midbuccal region was evaluated by subtracting PD from KG. The size of the graft in two dimensions was determined midway mesiodistally and corono-apically with a Michigan-O-Probe (Hu-Friedy, USA). The surface area of the transplanted tissue was calculated by multiplying the vertical and horizontal dimensions. The shrinkage of the graft in horizontal and vertical dimensions and the shrinkage of its surface area were also calculated according to this formula:

Postoperative value - preoperative value

Shrinkage $=$ $-100^{*}$

Preoperative value

The same investigator recorded these parameters at baseline and 1,3, and six months after the operation to evaluate the subsequent contraction of the graft.

\section{Statistical analysis}

One sample Kolmogorov Smirnov test revealed a normal distribution of the data ( $p>0.05)$. Repeated measures ANOVA, was utilized in order to analyze the data.

\section{Results}

All patients had mild to moderate pain after the surgery but there was no complication. Clinical parameters including PD, KG, AG, HD, VD and GA were recorded at baseline and 1, 3 , and six months after the operation (Figure 1 and Figure 2) (Table 1). PD was relatively fixed in test and control sites and did not differ significantly during six months $(p=0.258$, and $p=0.343$ respectively). The average change of other parameters in test and control sites (comparison between baseline and 6 months after surgery) respectively was as follows: KG increased $5.5 \mathrm{~mm}$, and $5.1 \mathrm{~mm}$, AG increased $5.3 \mathrm{~mm}$ and 5.1 $\mathrm{mm}, \mathrm{HD}$ shrinkage was $21.6 \%$ and $15.8 \%$, VD shrinkage was $33.7 \%$ and $33.2 \%$, GA shrinkage was $47.3 \%$ and $43.3 \%$. The increase of KG and AG and a decrease of HD and VD and GA were observed in test and control sites during the time, and these changes were statistically significant in each site according to the repeated measure test (Table 1). However, in general, there were no significant differences between test and control sites in any clinical parameter six months after surgery (Table 1).

\section{Discussion}

FGG is the most common technique for increasing keratinized, and attached gingiva $(8,12,13)$. After the FGG surgery, tissue shrinkage and dimensional changes occur, especially in long-term follow-up and may affect the outcome of treatment (6). One of the factors that influence the contraction of the FGG is suturing technique. In the present study, the effect of apical stretching and horizontal continues suturing on graft contraction was examined for the first time. The results of our study showed increasing of attached and keratinized gingiva in both test and control groups. The amount of keratinized gingiva was $5.5 \mathrm{~mm}$ and $5.1 \mathrm{~mm}$ in test and control groups respectively. Therefore, the average of keratinized gingiva width in the test was $0.4 \mathrm{~mm}$ more than control. The amount of attached gingival augmentation was
$5.3 \mathrm{~mm}$ in the case and $5.1 \mathrm{~mm}$ in control groups. In other words, the average increase in width of attached gingiva in test sites was $0.2 \mathrm{~mm}$ more than control sites. There was no statistical difference in the amount of keratinized and attached gingiva between test and control groups.

Silva (19) evaluated the healing of FGG in the anterior portion of the mandible in smokers in comparison with non-smokers. After three months, the mean width of keratinized gingiva was 5.4 and $4.8 \mathrm{~mm}$ in non-smokers and smokers respectively, but the difference between the two groups was not statistically significant. Wei, Laurell (14) compared the clinical results of FGG and alloderm regarding achieving increased attached gingiva. After six months, the keratinized gingival was $5.57 \mathrm{~mm}$ in FGG group and $2.59 \mathrm{~mm}$ in alloderm group. The difference was significant.

Agudio, Nieri (15) evaluated the long-term efficacy of FGG in 224 sites (103 patients). After one year, an average of keratinized gingiva was $4.2 \mathrm{~mm}$, and after 10-25 years, it was reduced to about $0.7 \mathrm{~mm}$. Harris (7) evaluated three different techniques (FGG, free connective tissue graft, and Allograft) and increasing the width of keratinized gingiva was statistically significant in all three groups. The result of FGG and Allograft was $4.1 \mathrm{~mm}$, and connective tissue graft was 3.6 $\mathrm{mm}$. After the free gingival grafts in 53 patients in Kovacevic (16) study, the gain of keratinized gingival was $5.41 \mathrm{~mm}$ that this gain was significant.

In the present study, the average of sulcular depth was reduced about $0.2 \mathrm{~mm}$ in the test group in comparison of a control group that no change was seen in sulcular depth. However, change of sulcular depth was not significant. In Egli, Vollmer (17) study, FGGs in 42 teeth $(n=12)$ evaluated for a year and did not see any change in probing depth. In the same study that performed by Rateitschak, Egli (18), no significant difference was recorded after four years. In Aquido study, sulcular probing depth remains constant after 1025 years old (15).

Our results showed that horizontal, vertical dimensions and the graft area were reduced in both the test and control group compared to pre-operative measurement, but it was not statistically significant. Therefore, the results of this study revealed that horizontal continuous and apical stretching did not have any effect in reducing shrinkage of the gingival graft. In the present study, the amount of horizontal shrinkage was $2.1 \mathrm{~mm}$ (21.6\%) while it was $1.5 \mathrm{~mm}(15.8 \%)$ in the control site. So in a clinical view, the amounts of horizontal contraction in the test group were $0.6 \mathrm{~mm}$ (5.8\%) more than the control group. The most percentage of horizontal contraction was $10.1 \%$ in the test group and $13.2 \%$ in the control group that occurred between the first and third months after the surgeries.

These results were comparable to Hatipoglu, Keceli (8) study that estimated horizontal shrinkage $10.2 \%$ after six months, and it is not statistically significant while it was in contrast with our study that was significant. In Silva study, the percentage of horizontal shrinkage was $22 \%$ in non-smokers and $25 \%$ in smokers that looks considerable, but the difference between the two groups was not significant (19). In the present study, vertical shrinkage was $3 \mathrm{~mm}(33.7 \%)$ in test and $2.8 \mathrm{~mm}$ (32.2\%) in control groups. In other words, the test group had more vertical graft contraction $(1.5 \%)$ than control groups. Most vertical shrinkage was $28.1 \%$ in the 
intervention group and $29.9 \%$ in the control group in the first month after surgeries. It was also observed that Vertical shrinkage was greater than horizontal contraction that was similar to Hatipoglu, Keceli (8) study. In the study above, average vertical shrinkage was $24.8 \%$ after six months and they reported statistical significant like our study.

Silva, Ribeiro Edel (19) showed vertical shrinkage in smokers was $44 \%$ versus in non-smokers reported $31 \%$ that the difference was not significant. The average vertical contraction was reported $25 \%$ within a year in Egli investigation (17). The results of Jung study showed vertical shrinkage in classic and strip technique was $29 \%$ and $28 \%$ respectively that did not find any significant difference (20).

In six months study of Wei, vertical shrinkage was reported $16 \%$ in FGG group and $71 \%$ in Allograft group that was statistically significant (14). In Kim study, the average vertical contraction after six months of free gingival grafts, connective tissue graft was $29 \%$ and $55 \%$ respectively. This difference was statistically significant (11). Rateitschak, Egli (18) estimated $25 \%$ vertical shrinkage after one year follow up.

In our study, area shrinkage was $47.3 \%$ in test and $43.3 \%$ in the control group. Therefore, in clinical view, the percentage of area shrinkage in the test was $4 \%$ more than the control group. The most percentage of area shrinkage was $33.8 \%$ in test and $33.1 \%$ in control sites after one month after surgery. These results are similar to Hatipoglu, Keceli (8) study that the average contraction of $35.3 \%$ was achieved six months after transplantation. In comparing smokers and non-smokers in Siva study, graft area shrinkage was $58 \%$ and $44 \%$ respectively. The changes in both groups were statistically significant, but the difference between the two groups was not statistically significant (19).

In the present study, using of Horizontal Continuous and Apical Stretching sutures does not seem to be efficient. Although the difference was not statistically significant between test and control groups, in term of clinical view, the percentage of graft shrinkage was more in intervention group that the most important factor could be trauma from an additional entry needle into the tissue. When the number of are increased to stabilize the graft, more trauma may exerted to the graft, and therefore, the probability of graft necrosis will increase. We can conclude that, using minimum number of sutures to stabilize the graft can be a factor which decrease the graft shrinkage.

One of our study limitations was low sample size which was because of budget and time shortage. The power analysis showed that a study with larger sample size can show the differences between two methods more accurately.

\section{Conclusion}

The findings of our study showed that using of apical stretching and continuous horizontal sutures do not provide any advantage in reducing graft shrinkage. Therefore, the use of the aforementioned sutures is not recommended.

Türkçe Öz: Türkçe başlık Yatay devamlı ve apikal esnetici dikişler SDG büzülmesini etkilemiyor: Split-Mouth randomize kontrollü klinik çalışma. Amaç: Bu çalışmada, yatay devamlı sutur ve apikal germe suturlarının Serbest diş etigreftinin büzülmesini azaltıp azaltmayacağı değerlendirildi. Gereç ve Yöntem: Bu randomize kontrollü klinik çalışmada, yetersiz keratinize ve yapışık diş eti bulunan, 18-53 (ort:39) yaş aralığın- da, 10 hastada $(7 K, 3 E)$ alt çene her iki kadranda Serbest diş eti grefti uygulandı. Test bölgelerinde, yaygın kullanılan sutur tekniklerine ek olarak yatay devamlı sutur ve apikal germe sutur kullanıldı. Sondalama derinliği(PD), keratinize ve yapışık diş eti genişliği (KG,AG), greftin yatay ve dikey boyutu $(H D, V D)$, greftin alanı $(G A)$ da dahil klinik parametreler başlangıçta, 1. Ve 3.ayda, ameliyattan 6 ay sonra kaydedildi. Bulgular: Sondalama derinliğinde (PD) 6 ay boyunca anlamlı fark görülmedi. Test ve kontrol bölgelerinde klinik parametrelerin ortalama değişimi sırasıyla, KG 5.5-5.1 mm arttı, AG 5.3-5.1 mm arttı, HD büzülme \%21.6-\%15.8, VD büzülme \%33.7-\%33.2, GA büzülme \%47.3-\%43.3 olarak belirlendi. Ameliyattan 6 ay sonra test ve kontrol bölgeleri arasında klinik parametrelerde anlamlı bir fark yoktu. Sonuç: Yatay devamlı sutur ve apikal germe sutur uygulaması serbest diş eti greftinin büzülmesini azaltmaz. Anahtar Kelimeler: Serbest diş eti grefti; greft büzülmesi; yatay devamlı sutur; apikal germe sutur; sondalama derinliği

Ethics Committee Approval: The ethics committee approved this research in Kerman University of Medical Science (Ethics code: KA/90/180) and registered through the IRCT website with the number IRCT201608205305N5.

Informed Consent: The informed consents were provided by the participants.

Peer-review: Externally peer-reviewed.

Author contributions: MM designed the study. AS participated in generating the data for the study. NA participated in gathering the data for the study. HR participated in the analysis of the data. AS and MM wrote the majority of the original draft of the paper. AS, MAS and MM participated in writing the paper. All authors approved the final version of this paper.

Conflict of Interest: The author had no conflict of interest to declare.

Financial Disclosure: The author declared that this study has received no financial support.

Acknowledgement: The author want to thanks Kerman University of medical sciences for funding this research.

\section{References}

1. Rancitelli D, Poli PP, Cicciu M, Lini F, Roncucci R, Cervino G, et al. Soft-Tissue Enhancement Combined With Biologically Oriented Preparation Technique to Correct Volumetric Bone Defects: A Clinical Case Report. J Oral Implantol 2017;43(4):307-13. [CrossRef]

2. Cifcibasi E, Karabey V, Koyuncuoglu C, Duzagac E, Genceli E, Kasali K, et al. Clinical evaluation of free gingival graft shrinkage in horizontal and vertical dimensions. J Istanb Univ Fac Dent 2015;49(3):11-6. [CrossRef]

3. Menceva Z, Dimitrovski O, Popovska M, Spasovski S, Spirov V, Petrushevska G. Free Gingival Graft versus Mucograft: Histological Evaluation. Open Access Maced J Med Sci 2018;6(4):675-9. [CrossRef]

4. Agarwal C, Kumar AT, Mehta DS. Comparative evaluation of free gingival graft and AlloDerm ${ }^{\oplus}$ in enhancing the width of attached gingival: A clinical study. Contemporary clinical dentistry 2015;6(4):483. [CrossRef]

5. Yuce HB. Official Publication of Cumhuriyet University Faculty of Dentistry. Cumhuriyet Dental Journal 2013;18(2):148-55.

6. Donoff RB. Biological basis for vestibuloplasty procedures. J Oral Surg 1976;34(10):890-6.

7. Harris RJ. Clinical evaluation of 3 techniques to augment keratinized tissue without root coverage. J Periodontol 2001;72(7):932-8. [CrossRef] 
8. Hatipoglu H, Keceli HG, Guncu GN, Sengun D, Tozum TF. Vertical and horizontal dimensional evaluation of free gingival grafts in the anterior mandible: a case report series. Clin Oral Investig 2007;11(2):107-13. [CrossRef]

9. Kim Y-J, Lim S-B, Chung $\mathrm{C}-\mathrm{H}$. The clinical study on shrinkage rate of graft following connective tissue autografts. The Journal of the Korean Academy of Periodontology 2000;30(3):639-49. [CrossRef]

10. Holbrook T, Ochsenbein C. Complete coverage of the denuded root surface with a one-stage gingival graft. Int J Periodontics Restorative Dent 1983;3(3):8-27.

11. Miller PD, Jr. Regenerative and reconstructive periodontal plastic surgery. Mucogingival surgery. Dent Clin North Am 1988;32(2):287-306.

12. Dorfman HS, Kennedy JE, Bird WC. Longitudinal evaluation of free autogenous gingival grafts. J Clin Periodontol 1980;7(4):31624. [CrossRef]

13. Dorfman HS, Kennedy JE, Bird WC. Longitudinal evaluation of free autogenous gingival grafts. A four year report. J Periodontol 1982;53(6):349-52. [CrossRef]

14. Wei PC, Laurell L, Lingen MW, Geivelis M. Acellular dermal matrix allografts to achieve increased attached gingiva. Part 2. A histological comparative study. J Periodontol 2002;73(3):25765. [CrossRef]
15. Agudio G, Nieri M, Rotundo R, Cortellini P, Pini Prato G. Free gingival grafts to increase keratinized tissue: a retrospective long-term evaluation ( 10 to 25 years) of outcomes. J Periodontol 2008;79(4):587-94. [CrossRef]

16. Kovacevic K. [Long-term therapeutic results following the application of free mucogingival autografts]. Stomatol Glas Srb 1991;37(5):491-501.

17. Egli U, Vollmer WH, Rateitschak KH. Follow-up studies of free gingival grafts. J Clin Periodontol 1975;2(2):98-104. [CrossRef]

18. Rateitschak KH, Egli U, Fringeli G. Recession: a 4-year longitudinal study after free gingival grafts. J Clin Periodontol 1979;6(3):15864. [CrossRef]

19. Silva CO, Ribeiro Edel P, Sallum AW, Tatakis DN. Free gingival grafts: graft shrinkage and donor-site healing in smokers and non-smokers. J Periodontol 2010;81(5):692-701. [CrossRef]

20. Jung HS, Lim SB, Chung $\mathrm{CH}$. The Clinical Study on Shrinkage Rate of Graft following Strip Gingival Autografts. The Journal of the Korean Academy of Periodontology. 1997;27(3):549-59. [CrossRef] 